\title{
Are Village Funds Effective in Improving Social Welfare in East Indonesia?
}

\author{
RUDY BADRUDIN ${ }^{1}$, BESTARI AYU DEWANTI ${ }^{2}$, BALDRIC SIREGAR ${ }^{3}$ \\ ${ }^{1}$ Department of Management, STIE YKPN SCHOOL OF BUSINESS, INDONESIA. \\ E-mail: rudybadrudin.stieykpn@gmail.com \\ 2Department of Accountancy, STIE YKPN SCHOOL OF BUSINESS, INDONESIA. E-mail: bestaridewanti@gmail.com \\ ${ }^{3}$ Department of Accountancy, STIE YKPN SCHOOL OF BUSINESS, INDONESIA. E-mail: baldricsiregar@gmail.com
}

\begin{abstract}
This study aims to analyze the effectiveness of village funds on social welfare of the district society in Maluku, North Maluku, Papua, and West Papua Provinces based on 2015-2018 data. The Village funds began to be distributed to all villages in these four provinces and other provinces in Indonesia in 2015. The data collection technique uses documentation technique, so that it produces secondary data in the form of a village funds, the Government Regional Budget, Gross Regional Domestic Product, and Human Development Index reports in four provinces which have been published on the official website of the Indonesian Statistics Agency. The sampling technique uses purposive sampling method with considerations in accordance with the objectives of the study. Based on the results of the regression analysis, it shows that village funds have not been able to influence on social welfare of the district society even though this has been accompanied by an allocation of capital expenditures and economic growth variables. There is a possibility that the size of the area in the villages in the four provinces and the quality of human resources for managing village funds in districts is an obstacle.
\end{abstract}

Keywords: village funds, capital expenditures, economic growth, social welfare

JEL Classification: O47, H53, R13 


\section{Introduction}

One of the main purposes of the establishment of Republic of Indonesia is the creation of public walfare. Indonesia was considered prosperous if all Indonesia citizen are in a state of sufficiency and not lacking anything matters or in the other words in a condition of safe and prosperous. Indonesia also have 5 main targers to increase Indonesia citizen welfare in the medium-term development plan. The first target is reducing percentage target of poverty and unemployment. The second target is giving priority to village by reducing development inequality to make sure that the gap among districts is decreased. Third target is to fulfilled citizens' social rights and increasing the quality of human's life. Fourth target is to manage natural resources in a better way, compared to the increasing of environmental quality. The fifth target is to increase the quantity and quality of development's supporting facilities and infrastructure support.

The economic growth can be used as reference to assess whether the economy of a country has been better compared to the previous year. This is very important thus it becomes a benchmark for a country to be considered to have a good or bad economy. In improving Community Welfare, a country must increase its economic growth to be better than previous year. In addition to increase economic growth, country also could allocate village funds and capital expenditure. Village funds are APBN funds obtained from districts/cities regional budget expenditure which shared to the villages through transfer process. Those funds can be utilized for financing Government management, construction, community development and for increasing welfare in rural places. Aside from economic growth and village funds, capital expenditure also can be used for increasing Community Welfare.

Capital expenditure is an expenditure which has value benefits more than 1 year. Capital expenditure also utilize to add various of fixed asset and as capital formation expenditure. Its also used for increase, improve, and maintain asset's useful life, including improving assets quality and capacity. In terms of those stated above, village funds and capital expenditure is expected to be able to improve economic growth so Community Welfare can also be affected. These will be counted as a success by measuring using Human Development Index (HDI). The Higher the HDI indicate that the regional regovernment is successful in creating the increase of human quality. 4 provinces used as our research objects are provinces that categorized as underdeveloped in its HDI achievement level in Indonesia.

\section{Literature Review}

\subsection{Agency Theory}

A theory that combines the principal and agent who operates in a service on behalf of the principal in a contract and the agent is authorized by the principal to be able for choosing decision in which they think best for the principal (Meckling, W. H., \& Jensen, 1976). In agency theory, the principal acts as a shareholder and the agent acts as management. The agent will know company condition and company information more compared to the principal at a later time.

Human are assumed to have 3 traits: Self Interest (always prioritize their own interest), Bounded Rationality (have minimal mindset about perception) and Risk Averse (In general, every person wants to avoid any risk) (Eisenhardt, 1989). Based on those assumption, both principal and agent want to get the same benefits but in the same time they also want to avoid risk, which in the end will create conflict (Jensen dan Meckling, 1976). In the government, agent is the government itselves and principal is the public. The public elect government as an agent, so the agent must be responsible for realizing Community Welfare and carrying out obligations in accordance with the Constitution (Nurdiono et al, 2016).

\subsection{Fiscal Decentralization Theory}

Fiscal decentralization is a method used by the country to achive Community Welfare by encourage regional and national governments in managing the development through a better financial 
management so that it can have impact on a better economy by implementing regional development Rochjadi (2006:7-8).

Fiscal decentralization can be measured using revenue component obtained from the regional and the regional budget expenditure. The revenue earned by the region is an increase recognized as a right acquired by the government as the value of net worth. Regional revenue has 3 sources: locally generated revenue, balancing fund, and legal regional revenue. Regional expenses are cost incurred by the region. Regional expenditure is regional expenses that can be enjoyed fairly by all society, especially in terms of public services. Regional expenditure consists of capital and routine expenditure.

\subsection{Village Funds}

Village Funds is fund shared to the village obtained from State Budget through transfers of regional/city budget expenditure. Managing village funds appropriately can improve rural communities' life. Aspiration and Control from rural communities also needed for creating more prosperous village. Village funds are prioritized not only for building and empowering the public, but also for improving the human quality and reducing poverty.

\subsection{Capital Expenditure}

Capital expenditure is one of the provision of goods and services by the government, from the planning process to obtaining the goods or services. An expenditure can be categorized as capital expenditure if the money spent was used for adding government assets, have economic life more than 1 year and if the asset was not for sale. Broadly speaking, capital expenditure was believed to be able to improve economic growth.

\subsection{Economic Development and Economic Growth}

Adam Smith stated that there are 2 aspect in enonomic growth. The first is total output growth in which as main element such as availability of natural resources, human resources, and stock of capital goods. The second aspect is population growth. David Ricardo stated that economic development and economic growth are mainly based on output growth rate and population growth rate. Limited land production factors and labor production factors are resulting in decreased of marginal products, which usually called as the law of diminishing returns. This caused by the labor received salary above the lowest standard, which can affect not only the population growth but also the marginal products, which will press the labor rate into lower value. The performance of the law of diminishing returns can be delayed by accumulating capital production factors and technological advances.

According to Solow Swan, the growth and development of economics are depend on the increase of population, labor, accumulated of capital production, and technological advanes. Harrod-Domar also explain about the condition needed so the economic can be developed and grow in a long term. Harrod-Domar also stated that investment is an expenditure which can produced goods and services. Nicholas Kaldor stated that based on stylized facts there are 2 approaches in Economic Growth Theory and Economic Development Theory, which are Neo-Keynes and Neo-Classic. Things that differs those 2 approaches are the framework idea on the problems arise in economic growth.

\subsection{Community Welfare}

Community Welfare is achived when whole society in a state of sufficient, not lack of anything matters or safe and prosperous. In this case, first is the distribution of basic needs such as foods, housing, health, and protection are developed and equal in all society. Second, level of life quality, earning level, culture and education, and human value are experiencing more attention. The third one is economies of scale are expanded and the existence of social selected both from individuals and nations.

A society is called prosperous if Indonesia is free from economical problem, has more jobs and more business activities are created. A society is called prosperous if Indonesian citizen can have access to 
higher education level in an easy and cheap way, so that high education can not only be obtained by people with good or sufficient economies. An easy and expensive education is expected to be accessible to all level of citizen. Indonesia can also be stated as prosperous if the society didn't complain about the healthcare quality in Indonesia.

\subsection{The Impact of Village Funds to Community Welfare}

A numerous study has been conducted about the impact of village funds to Community Welfare, such as (Nurohman et al., 2019) in which resulted that village funds allocation can effect the Community Welfare negatively. This is different than the research done by (Sunu \& Utama, 2019), which resulted that village funds have positive effect to Community Welfare. The same research is done by (Rimawan \& Aryani, 2019), and the result is allocation of village funds can positively effect the Human Development Index (HDI). The higher the IPM, the more prosperous the society will be. Study conducted by Sunu, Utama, Rimawan and Aryani also supported by (Rusydi, 2012) in which resulted that allocation of village funds have positive effect to Community Welfare.

$\mathrm{H}_{1}$ : Village Funds have positive effect on the Community Welfare of district community in Maluku, North Maluku, Papua, and West Papua Provinces Year 2015-2018

\subsection{The impact of Capital Expenditure to Community Welfare}

Several studies have been conducted on the impact of capital expenditure to Community Welfare, such as (Badrudin \& Kuncorojati, 2017) in which resulted that capital expenditure did not significantly affect the Community Welfare. Unlike the study conducted by (Tampubolon, 2019), Tampubolon stated that capital expenditure have positive effect on Community Welfare. (Mirza, 2012) also found that capital expenditure has positive effect on human development index. Both Tampubolon and Mirza study are supported by (Firmansyah, 2015), in which resulted that Capital expenditure has positive effect significantly on human development index (HDI).

$\mathrm{H}_{2}$ : Capital Expenditure has positive effect on the Community Welfare of district community in Maluku, North Maluku, Papua, and West Papua Provinces Year 2015-2018

\subsection{The Impact of Economic Growth to Community Welfare}

In improving Community Welfare, government needs to increase economic growth. Economic growth is one of benchmark of a country to be categorized as having a good economic or not. A good economic indicate a good Community Welfare. Several studies are conducted to research the impact of economic growth to Community Welfare. (Siregar \& Badrudin, 2019) shown that economic growth did not significantly affect the social welfare. This study is supported by (Pratiwi \& Indrajaya, 2019) that economic growth did not positively effect to Community Welfare. In contrast to the study conducted by (Yasa \& Arka, 2015), in which resulted that economic growth have significantly positive effect to Community Welfare. Mirza (2012) also conducted a study resulted that economic growth has significantly positive effect to HDI. Study conducted by Yasa, Arka and Mirza also supported by Firmansyah (2012), which shown that economic growth has significantly positive effect on HDI.

$\mathrm{H}_{3}$ : Economic growth has positive effect on the Community Welfare of district community in Maluku, North Maluku, Papua, and West Papua Provinces Year 2015-2018

\section{Methodology}

This study is using secondary datas. The sampling technique used in this study is purposive sampling. This technique intentionally/ not randomly taking sample criteria in accordance with the objectives and problems in the study. This study is using samples which characteristics are all districts in Maluku, North Maluku, Papua, and West Papua Provinces year 2015-2018. The researcher get all the data in the form of Detailed Village Funds Report, Realization Report of Regional State Budget, Gross Regional Domestic Product data, and Human Development Index data of districts in Maluku, 
North Maluku, Papua, and West Papua Provinces year 2015-2018. All datas are published by BPS Indonesia.

\section{Results and Findings}

Total data used in this study is amounted 210. Variable of districs's village funds in Maluku, North Maluku, Papua, and West Papua has minimum value of Rp12,131,809,000, in which own by District Supiori in Papua Province year 2015, and maximum value of Rp365,435,608,000 in which own by district Tolikara in Papua Province year 2018. The average value is $\mathrm{Rp} 96,754,807,142$ and the standard deviation value is Rp63,224,145,436.

Variable of district's Capital Expenditure in Maluku, North Maluku, Papua, and West Papua Provinces has minimum value of Rp111,169,996,719, which own by district Biak Numfor located in Papua Province in 2018 and maximum value of Rp677,895,106,172, which own by district Puncak located in Papua Province in 2015. The average value is Rp282,177,416,374 the standard deviation value is Rp101,592,666,313. Variable of district's economic growth in Maluku, North Maluku, Papua, and West Papua Provinces has minimum value of $0.38 \%$, which own by district East Seram located in Maluku Provinces in 2018 and maximum value of $10.30 \%$, which own by district Mamberamo Raya located in Papua Provinces in 2015. The average value is $5.84 \%$ and the standard deviation is $1.56 \%$.

Table 1 Descriptive Statistics

\begin{tabular}{|c|c|c|c|c|c|}
\hline Variable & N & Minimum & Maximum & Average & Standard Deviation \\
\hline DD & 210 & $R p 12,131,809,000$ & $R p 365,435,608,000$ & $R p 96,754,807,142$ & $R p 63,224,145,436$ \\
\hline BM & 210 & $R p 111,169,996,719$ & $R p 677,895,106,172$ & $R p 282,177,416,374$ & $R p 101,592,666,313$ \\
\hline PE & 210 & $0.38 \%$ & $10.30 \%$ & $5.84 \%$ & $1.56 \%$ \\
\hline IPM & 210 & 25.47 & 72.42 & 58.15 & 9.07 \\
\hline
\end{tabular}

Note: DD: Village Funds $\quad$ BM: Capital Expenditure $\quad$ PE: Economic Growth IPM: Community Welfare

Minimum value on Variable IPM (Community Welfare) of districts' society in Maluku, North Maluku, Papua, and West Papua Provinces is 25.47 which own by district Nduga located in Papua Provinces year 2015 and maximum value on Variable IPM is 72.42, which own by district Mimika located in Papua Provinces year 2017. The average value is 58.15 and the standard deviation is 9.07.

Table 2 Normality Test

\begin{tabular}{|c|c|}
\hline Significance & Note \\
\hline 0,8654 & Normal Distribution \\
\hline
\end{tabular}

Significance value is $0.8654>0.05$, which means the data is normally distributed, so that the research data meets the requirements of the normality test.

Table 3 Multicollinearity Test

\begin{tabular}{|c|c|c|c|}
\hline \multirow{2}{*}{ Variable } & \multicolumn{2}{|c|}{ Collinearity Statistics } & \multirow{2}{*}{ Note } \\
\cline { 2 - 4 } & Tolerance & VIF & No Multicollinearity \\
\hline DD & 0.9620 & 1.0395 & No Multicollinearity \\
\hline BM & 0.9637 & 1.0376 & No Multicollinearity \\
\hline PE & 0.9622 & 1.0393 & \\
\hline
\end{tabular}

Note: DD: Village Funds

BM: Capital Expenditure

PE: Economic Growth

Based on those result, it can be conluded that all independent variable do not have multicollinearity problem because the tolerance value is above 0.10 and the VIF is below 10 . 
Table 4 Heteroscedasticity Test

\begin{tabular}{|c|c|c|}
\hline Variable & Sig. & Note \\
\hline DD & 0,1540 & No Heteroscedasticity \\
\hline BM & 0,5932 & No Heteroscedasticity \\
\hline PE & 0,3877 & No Heteroscedasticity \\
\hline
\end{tabular}

Note: DD: Village Funds

BM: Capital Expenditure

PE: Economic Growth

Based on those result, it can be conluded that all independent variable do not have heteroscedasticity problem because the signifance value is above 0.05 .

Table 5 Autocorrelation Test

\begin{tabular}{|c|c|c|c|c|c|}
\hline $\mathbf{N}$ & $\mathbf{D W}$ & $\mathbf{d L}$ & $\mathbf{d U}$ & 4-dL & 4-dU \\
\hline 210 & 1,97921 & 1,74513 & 1,80305 & 2,25487 & 2,19695 \\
\hline Result & \multicolumn{5}{|c|}{ No Autocorrelation } \\
\hline
\end{tabular}

Autocorrelation Test result shown that Durbin Watson (dw) value is 1.97921, with the amount of independent variable $(\mathrm{k})=3$, and sample used in the study is 210 . Therefore, $\mathrm{dL}$ value $=1.74513$, $\mathrm{dU}$ value $=1.80305,4-\mathrm{dL}$ value $=2.25487$, and $4-\mathrm{dU}$ value $=2.19695$, which means $\mathrm{dU}<\mathrm{dW}<4-\mathrm{dU}$ or $1.80305<1.97921<2.19695$. From the result above, can be conluded that the regression model used in the study do not have any autocorrelation problem.

Table 6 Partial Test Result (T Test)

\begin{tabular}{|c|c|c|c|c|c|}
\hline Hypothesis & Regression Coefficient & T Value & Prob. Sig. & Prediction & Finding \\
\hline H1 & -0.0459 & -2.6996 & 0.0075 & Positive & Negative \\
\hline H2 & -0.1658 & -4.9483 & 0.0000 & Positive & Negative \\
\hline H3 & -0.0401 & -1.3588 & 0.1757 & Positive & Negative \\
\hline
\end{tabular}

\subsection{The Impact of Village Funds to Community Welfare}

Based on the study conducted by researcher, it shown that village funds have negative effect on the Community Welfare of district society in Maluku, North Maluku, Papua, and West Papua Provinces Year 2015-2018. The result also supported through hypothesis testing in which the regression coefficient value is $-0, .0459$ with negative sign and has $t$-value of -2.6996 (below t-table 1.645) and has probability significance value 0.0075 (below 0.05 ), therefore $\mathrm{H} 1$ is rejected. Village funds can be used to improve Community Welfare, unfortunately those funds have not been used optimally, nor effective or efficient. It can be caused by those village funds are less evenly distributed and maybe misdirected, such as underdeveloped village, unreachable village, fictional villages, or the possibility of misuse of village funds. This result is supported by the study of Nurohman, Qurniawati, dan Hasyim (2019), but in contrary with the result of Sunu dan Utama (2019) dan Rimawan dan Aryani (2019) which stated that village funds have significant positive effect on Community Welfare.

\subsection{The Impact of Capital Expenditure to Community Welfare}

Based on the study conducted by researcher, it shown that capital expenditure has negative effect on the Community Welfare of district society in Maluku, North Maluku, Papua, and West Papua Provinces Year 2015-2018. The result also supported through hypothesis testing in which the regression coefficient value is -0.1658 with negative sign and has $t$-value of -4.9483 (below $t$-table 1.645) and has probability significance value 0.0000 (below 0.05 ), therefore $\mathrm{H} 2$ is rejected. Capital expenditures have benefits to increase, improve, and maintaining the useful life of assets, including increasing the quality and the capacity of assets therefore it can be able for increasing Community Welfare. Unfortunately, in this study the capital expenditure has not fully utilized, which can be caused by the possibility of using capital expenditures to purchase government office assets that cannot be used directly by the public, the possibility of misuse of funds that are not in accordance with the procedures and also misuse of funds by individuals. The result is supported by Badrudin dan 
Kuncorojati (2017), but in contrary with the study conducted by Tampubolon (2019), Mirza (2011) dan Firmansyah (2015), that capital expenditure has positive effect on Community Welfare.

\subsection{The Impact of Economic Growth to Community Welfare}

Based on the study conducted by researcher, it shown that economic growth has negative effect on the Community Welfare of district society in Maluku, North Maluku, Papua, and West Papua Provinces Year 2015-2018. The result also supported through hypothesis testing in which the regression coefficient value is -0.0401 with negative sign and has $t$-value of -1.3588 (below $t$-table 1.645) and has probability significance value 0.1757 (below 0.05 ), therefore $\mathrm{H} 3$ is rejected. The economic growth does not affect the Community Welfare, which caused by there is no development carried out by government to increase the economics in the society, which also causes lack of employment. The society tends not to work, and even if there are any development, those are exclusive, which means those development only can benefit society with the capital only. People who do not work will result in a low economy and unfulfilled basic needs, such as health needs and education needs. These basic needs fulfilment is things that can increase Community Welfare. The result is supported by Baldric dan Badrudin (2019), Pratiwi dan Indrajaya (2019), but in contrary with the study conducted by Yasa dan Arka (2015) dan Firmansyah (2015), that economic growth has positive effect on Community Welfare.

\section{Conclusion}

Village funds have negative effect on Community Welfare of districts society in Maluku, North Maluku, Papua, and West Papua Provinces Year 2015-2018. Based on the result, it can be concluded that village funds can not fully utilized to increase Community Welfare. It can be caused by the possibility of less evenly distributed of village funds and misdirected of village funds, such as underdeveloped village, unreachable village, fictional villages, or the possibility of misuse of village funds.

Capital expenditures has negative effect on Community Welfare of districts society in Maluku, North Maluku, Papua, and West Papua Provinces Year 2015-2018. Based on the result, the capital expenditure can not fully utilized for increasing Community Welfare, which can be caused by the possibility of using capital expenditures to purchase government office assets that cannot be used directly by the public, the possibility of misuse of funds that are not in accordance with the procedures and also misuse of funds by individuals.

The economic growth does not affect the Community Welfare of districts society in Maluku, North Maluku, Papua, and West Papua Provinces Year 2015-2018. Based on the result, the increase of economic growth is not followed by the increase of Community Welfare. This is caused by there is no development carried out by government to increase the economics in the society, which also causes lack of employment. The society tends not to work, and even if there are any development, those are exclusive, which means those development only can benefit society with the capital only. People who do not work will result in a low economy and unfulfilled basic needs, such as health needs and education needs. These basic needs fulfilment is things that can increase Community Welfare.

The district government in Maluku, North Maluku, Papua, and West Papua Provinces should be able to manage village funds and capital expenditure in the best possible way, utilize village funds and capital expenditure according to the procedures and they should start the development to create more employment for the public. Managing the village funds and capital expenditure appropriately and also balancing with a better economic growth can improve Community Welfare. Further researchers are suggested to adding more timeframe in order to describe changes overtime better. Adding more districts and provinces are also suggested to increase the data samples, therefore can improve the accuracy of the study. Further researchers also suggested to add more research variables, such as poverty indicator level which can be able to measure Community Welfare. 


\section{Acknowledgment}

This research work is supported by the Project of Penelitian Dasar scheme in 2020 and 2021 (No. B/87/E3/RA.00/2020, 28 January 2020), supported by KEMENRISTEK/BRIN Republic of Indonesia.

\section{References}

1. Badrudin, R., \& Kuncorojati, I. (2017). The Effect Of District Own-Source Revenue And Balance Funds On Community Welfare By Capital Expenditure and Economic Growth As An Intervening Variable In Special District Of Yogyakarta. Jurnal Manajemen Dan Kewirausahaan, 19(1), 54-59. https://doi.org/10.9744/jmk.19.1.54

2. Eisenhardt, K. M. (1989). Agency Theory: An Assessment and Review Linked references are available on JSTOR for this article: Agency Theory: An Assessment and Review. Academy of Management Review, 14(1), 57-74.

3. Firmansyah. (2015). Pengaruh Dana Perimbangan, Belanja Modal, Pertumbuhan Ekonomi, dan Kemiskinan Terhadap IPM Kabupaten/Kota di Provinsi Banten. Skripsi. https://dspace.uii.ac.id/bitstream/handle/123456789/991/08\%20naskah\%20publikasi.pdf?seque nce $=15 \&$ isAllowed $=y$

4. Jensen, M. C., \& Meckling, W. H. (1976). Managerial behavior, agency costs and ownership structureMeckling, W. H., \& Jensen, M. C. (1976). Managerial behavior, agency costs and ownership structure. Journal of Financial Economics. https://doi.org/DOI: 10.1016/0304-405X(76)90026-X. Journal of Financial Economics.

5. Mirza, D. (2012). Pengaruh Kemiskinan, Pertumbuhan Ekonomi, Dan Belanja Modal Terhadap Indeks Pembangunan Manusia Di Jawa Tengah Tahun 2006-2009. Economics Development Analysis Journal, 1(1), 2-15. https://doi.org/10.15294/edaj.v1i2.474

6. Nurdiono, N. S., Sugiri, A. Halim, et al. 2016. "The Effect Of Budget's Proportion and Non-financial Factors On The Audit Result Of Local Government Financial Statements in Indonesia." Journal Of Indonesia Economy and Business, 31 (9):178-191.

7. Nurohman, Y., Qurniawati, R., \& Hasyim, F. (2019). Dana Desa Dalam Peningkatan Kesejahteraan Masyarakat Pada Desa Wisata Menggoro. Magisma: Jurnal Ilmiah Ekonomi Dan Bisnis, 7(1), 35-43. https://doi.org/10.35829/magisma.v7i1.38

8. Pratiwi, N., \& Indrajaya, I. (2019). Pengaruh Pertumbuhan Ekonomi dan Pengeluaran Pemerintah Terhadap Penyerapan Tenaga Kerja Serta Kesejahteraan Masyarakat di Provinsi Bali. Buletin Studi EKonomi, 24(2), 220-233.

9. Rimawan, M., \& Aryani, F. (2019). Pengaruh Alokasi Dana Desa Terhadap Pertumbuhan Ekonomi , Indeks Pembangunan Manusia Serta Kemiskinan di Kabupaten Bima. Jurnal Ilmiah Akuntansi Dan Humanika, 9(3), 287-295.

10. Rochjadi, Achmad. 2006. Tinjauan Pelaksanaan Hubungan Keuangan Pusat dan Daerah Tahun 20042005. Jakarta: Kementerian Keuangan.

11.Rusydi, H. (2012). Pengaruh Alokasi Dana Desa (ADD) Terhadap Kesejahteraan Masyarakat Desa di Kabupaten Takalar. Jurnal Ekonomi Balance, 8(2), 152-176.

12.Siregar, \& Badrudin. (2019). The Evaluation of Fiscal Decentralization in Indonesia Based on the Degree of Regional Autonomy. Journal of Reviews on Global Economics, 8, 611-624. https://doi.org/10.6000/1929-7092.2019.08.53

13.Sunu, M., \& Utama, M. (2019). Pengaruh Dana Desa Terhadap Tingkat Kemiskinan Dan Kesejahteraan Masyarakat Di Kabupaten/Kota Provinsi Bali. E-Jurnal Ekonomi Dan Bisnis Universitas Udayana, 8, 843-872. https://doi.org/10.24843/eeb.2019.v08.i08.p02

14.Tampubolon, E. (2019). Pengaruh Belanja Modal Terhadap Kesejahteraan Masyarakat. Sosio ekons, 11(1), 79-89. 
15.Yasa, I., \& Arka, S. (2015). Pengaruh Pertumbuhan Ekonomi Dan Disparitas Pendapatan Antardaerah Terhadap Kesejahteraan Masyarakat Provinsi Bali. Jurnal Ekonomi Kuantitatif Terapan, 8(1), 63-71. 